\title{
ASSESSMENT OF THE SOCIAL BURDEN ON PATIENTS WITH PRIMARY OPEN-ANGLE GLAUCOMA
}

\author{
Zoran Velkovski ${ }^{1}$ Maja Belevska², Emilija Gjosevska Dastevska
}

\begin{abstract}
Glaucoma is a chronic ophthalmic disease characterized by progressive, irreversible loss of visual acuity, long-term progression and lifelong treatment, declining work ability and self-sufficiency, which can generate social burden in patients. The study is designed to understand the social, clinical and pharmacological aspects of assessing the social burden of primary open-angle glaucoma. It is a cross-sectional study with a quantitative analytical approach, which includes 182 male and female patients with primary open-angle glaucoma, aged 20-67, with preserved visual acuity > 6/18 (0.33), according to the ICD-10 classification, conducted in the period August-November 2020 on the territory of North Macedonia. Fifty-three point three percent of the respondents were female and $46.7 \%$ male, of whom $79.12 \%$ were treated with prescribed medications, $8.8 \%$ with laser and $12.08 \%$ underwent a surgical procedure. Fifty-seven point sixty-nine percent of the respondents received treatment regularly, which in $43.96 \%$ had a negative outcome, partial success in $30.22 \%$, and in $25.82 \%$, the treatment prevented further vision loss. Fourteen point twenty-eight percent of the respondents experienced a social family burden and $34.07 \%$ discomfort, depression, anxiety, hopelessness and other psychosocial disorders. Primary open-angle glaucoma generates a significant socioeconomic burden as a result of irreversible visual impairment, reduced work ability and productivity, and high treatment costs of patients. The degree of the social burden depends on the evolvement and clinical stage of the disease, the percentage of preserved vision, availability, manner and regularity of treatment and socio-demographic parameters such as gender, age, occupation, genetic predisposition, comorbid conditions, family history, etc. which in glaucoma play the role of predisposing risk factors.
\end{abstract}

Acta Medica Medianae 2021;60(4):30-38.

Key words: primary open-angle glaucoma, social burden, socio-demographic parameters, treatment

${ }^{1}$ Clinical Hospital Bitola, Department of Laboratory Diagnostics, Bitola, North Macedonia

${ }^{2}$ Clinical Hospital Bitola, Department of Ophthalmology, Bitola, North Macedonia

${ }^{3}$ Faculty of Medicine Skopje, Clinic for Eye Diseases, Skopje, North Macedonia

Contact: Zoran Velkovski

Partizanska bb, 7000 Bitola, North Macedonia

E-mail: zoranv_mk@yahoo.com

\section{Introduction}

The eye disorder caused by glaucoma is one of the most common pathological conditions in ophthalmology. It affects all ages, both genders, all occupations, people of different social categories and existential status and depending on the clinical stage, the severity of the clinical picture and the degree of the preserved acuity, it generates more or less pronounced individual and family social burden to the diseased people (1-3).

Glaucoma is an optic neuropathy which is characterized by damage to the papilla of the optic nerve, specific defects in the visual field and progressive irreversible loss of visual function $(4,5)$.

Glaucoma has a prevalence of $1-2 \%$ in the world's population and it is the second most common cause of irreversible vision loss after cataracts, accounting for $13 \%$ of all cases of global blindness (6-8). Primary open-angle glaucoma accounts for $75 \%$ of all glaucoma cases, $55 \%$ of which are female (9).

Clinically, they start with non-specific symptoms, which is why they are usually diagnosed in the later clinical stages, after 40 years of age. Due to the long asymptomatic period, in addition to the diagnosed ones, there are more than $60 \%$ of still undiagnosed cases of the disease $(10,11)$.

Primary open-angle glaucoma generates individual and family social burden on patients and has 
a huge socio-economic impact on the population and society (12-14).

The decreased visual acuity impedes mobility and leads to difficulties in movement, spatial orientation, recognition of objects and people in the surroundings, performing daily obligations and taking care of oneself without any assistance of others (15, 16).

The opportunities for education, training, employment, socialization, interaction are limited, and as a consequence they live stigmatized on the margins of society, often experiencing hopelessness and loss of independence (17).

The long-term, usually lifelong, daily use of antiglaucoma therapy causes discomfort, adverse local reactions accompanied by pain and recurrent infections in patients (18-20). Topical administration of beta-blockers containing preservatives may cause erosions and inflammation of the cornea, secondary cataracts and systemic adverse reactions in the form of bronchial asthma $(21,22)$.

Progressive loss of visual acuity, uncertainty of the outcome and the possibility of blindness can cause discomfort, anxiety, depression and other mental disorders in patients $(23,24)$.

The Health-Related Quality of Life (HRQL) as one of the main determinants (predictors) which define the subjective perception of well-being, social status, and thus the social burden which is reflected on the diseased, according to Guantiamo and Floriani, are inversely related to the degree of lost visual acuity $(25,26)$.

\section{Purpose}

The study is designed to determine the social, clinical and pharmacological aspects when assessing the social burden on patients with primary openangle glaucoma.

\section{Materials and methods}

It is a cross sectional study with a quantitative analytical approach conducted in the period between August and November of 2020 on the territory of North Macedonia, which included 182 male and female employed respondents with primary open-angle glaucoma, aged 20-67.

The research was carried out using clinical history and a custom designed survey, whereas the patients' diagnoses were confirmed by a clinical ophthalmological examination and the accompanying medical history. The clinical research and surveys were performed within the periodic health examinations, while the degree of impaired vision was determined according to the ICD 10 classification, which ranged from 0.7 to 0.3 of affected people. All the respondents were diagnosed with primary openangle glaucoma at different clinical stages with progression over a period from 2 to 20 years.

The socio-demographic parameters of the respondents included in the study were assessed according to gender, age, education, occupation, family burden, individual consequential predictors (discomfort, depression, anxiety), whereas the clinicalpharmacological assessment included method of treatment, duration of treatment, regularity in taking prescribed medication and outcome of treatment.

The statistical data processing was performed using descriptive and comparative statistical procedures, utilising statistical programmes such as statistics for Windows 7.0 and SPSS 17.0.

Pearson Chi-square homogeneity test was used to determine the differences in the attributive values of dichotomous features (variables) between male and female respondents, while a non-parametric Mann-Whitney Test was used to determine the significance of the differences in the independent features (variables). To determine the statistical significance, a significance level is determined, $p<$ 0.05 . The obtained results are presented numerically and in tables.

\section{Results}

The scientific study included 182 people aged 20-67, patients with primary open-angle glaucoma, of whom 85 (46.70\%) were male and 97 (53.30\%) were female and were organised into 3 age groups, 20-50, 51-60 and 61-67 (Table 1).

Table 1. Structure of the respondents by age and gender

\begin{tabular}{|c|c||c|c||c||}
\hline \multicolumn{2}{|c||}{ Age } & \multicolumn{2}{c||}{ Gender } & \multirow{2}{*}{ Total } \\
\cline { 2 - 5 } & Male & Female & \\
\hline \multirow{2}{*}{ Age 20-50 } & Number & 15 & 20 & 35 \\
\cline { 2 - 5 } & $\%$ & 8.24 & 1099 & 19.23 \\
\hline \hline \multirow{2}{*}{ Age 51-60 } & Number & 38 & 40 & 78 \\
\cline { 2 - 5 } & $\%$ & 20.88 & 2198 & 42.86 \\
\hline \hline \multirow{2}{*}{ Age 61-67 } & Number & 32 & 37 & 69 \\
\cline { 2 - 5 } & $\%$ & 17.58 & 20.33 & 37.91 \\
\hline \hline \multirow{2}{*}{ Total } & Number & 85 & 97 & 182 \\
\cline { 2 - 5 } & $\%$ & 46.70 & 53.30 & 100 \\
\hline
\end{tabular}

Pearson Chi-square $=4.02721, \mathrm{df}=2, \mathrm{p}=0.083576$ 
Eighty-five $(46.70 \%)$ of the respondents included in the research were male and $97(53.30 \%)$ were female. Thirty-five $(19.23 \%)$ of whom were up to 50 years of age, $78(42.86 \%)$ were aged $51-60$, and $69(37.91 \%)$ between 61 and 67, i.e. most of the respondents, male or female, were aged 51-60. The statistical analysis showed that there was no significant age difference between the two genders (Pearson Chi-square $=4.02721, \mathrm{df}=2, \mathrm{p}=$ 0.083576 ). The youngest respondent in the research was 44 , and the oldest 67.

A descriptive analysis was also made on the individual age of all respondents involved in the study (Table 2).

The average age of the male respondents included in the study was 57.85 , SD 6.343 , median 59 , minimum age 44 and maximum age 67 , and the average age of the female respondents was 57.40, SD 6.858, median 59, minimum age 44 and maximum age 67 .
Statistical analysis showed that no significant difference was observed between the two genders in terms of age (Mann-Whitney U Test $Z=0.373668 p$ $=0.804904$ ).

The respondents involved in the scientific study had different education and occupation. The employees with primary education were of different occupations, and most of them were construction and agricultural workers, workers in the cardboard industry, telephone operators, porters, craftsmen, etc., while in the rest of the patients, those with secondary and higher education, different occupations predominated (Table 3 ).

Sixty-two $(34.07 \%)$ of the respondents included in the study had a career with primary education, $77(42.31 \%)$ with secondary education, and $43(23.62 \%)$ with higher education. Statistical analysis showed that there is no significant difference in terms of these parameters with male and female respondents (Pearson Chi-square $=2.96, \mathrm{df}=2, \mathrm{p}$ $=0.1138)$.

Table 2. Descriptive analysis of the age of the respondents

\begin{tabular}{||c||c|c|c|c|c|c|c||}
\hline \hline Gender & $\begin{array}{c}\text { Number } \\
\text { of people }\end{array}$ & $\begin{array}{c}\text { Average value } \\
\text { (Means) }\end{array}$ & $\begin{array}{c}\text { Standard } \\
\text { deviation } \\
\text { (Std.Dev.) }\end{array}$ & $\begin{array}{c}\text { Standard } \\
\text { Error } \\
\text { (Std.Err.) }\end{array}$ & (Median) & (Min) & (Max) \\
\hline \hline Male & 85 & 57.85 & 6.343 & 1.255504 & 59 & 44 & 67 \\
\hline Female & 97 & 57.40 & 6.858 & 1.418532 & 59 & 44 & 67 \\
\hline \hline Total & 182 & 57.63 & 6.601 & 0.944411 & 59 & 44 & 67 \\
\hline
\end{tabular}

Mann-Whitney U Test Z $=0.373668, p=0.804904$

Table 3. Structure of the respondents by occupation/education

\begin{tabular}{|c|c||c|c||c||}
\hline \multirow{2}{*}{ Occupation/education } & \multicolumn{2}{c||}{ Gender } & \multirow{2}{*}{ Total } \\
\cline { 2 - 5 } & & Male & Female & \\
\hline \hline \multirow{2}{*}{$\begin{array}{c}\text { Occupation with } \\
\text { primary education }\end{array}$} & Number & 29 & 33 & 62 \\
\cline { 2 - 5 } & $\%$ & 15.93 & 18.13 & 34.07 \\
\hline \hline $\begin{array}{c}\text { Occupation with } \\
\text { secondary education }\end{array}$ & Number & 36 & 41 & 77 \\
\cline { 2 - 5 } & $\%$ & 19.78 & 22.53 & 42.31 \\
\hline \hline $\begin{array}{c}\text { Occupation with } \\
\text { higher education }\end{array}$ & Number & 20 & 23 & 43 \\
\cline { 2 - 5 } & $\%$ & 10.99 & 12.64 & 23.62 \\
\hline \hline \multirow{2}{*}{ Total } & Number & 85 & 97 & 182 \\
\cline { 2 - 5 } & $\%$ & 46.70 & 53.30 & 100 \\
\hline
\end{tabular}

Pearson Chi-square $=2.96, \mathrm{df}=2, \mathrm{p}=0.1138$

From the socio-demographic characteristics, the parameter place of residence, city/village (urban/rural environment) was also analysed among the surveyed respondents (Table 4).

Out of the total of 182 people, 139 (76.37\%) lived in urban areas and $43(23.63 \%)$ in rural areas. $65(35.71 \%)$ of the male respondents lived in the city and $20(10.99 \%)$ in the countryside, and the largest number $74(40.66 \%)$ of the female respondents also lived in the city, $23(12.64 \%)$ in the countryside. There is no statistically significant difference in terms of place of residence between male and female respondents (Pearson Chi-square $=$ 2.713, $\mathrm{df}=1, \mathrm{p}=0.132$ ).

All patients included in the study were treated with pharmacotherapy, while in the cases of unsuccessful treatment and progression of visual impairment some of them received laser therapy or surgery (Table 5). 
Table 4. Place of residence of respondents

\begin{tabular}{|c|c||c|c|c||}
\hline \multicolumn{2}{|c||}{ Place of residence } & \multicolumn{2}{c|}{ Gender } & \multirow{2}{*}{ Total } \\
\cline { 2 - 5 } & & Male & Female & \\
\hline \hline \multirow{2}{*}{ City } & Number & 65 & 74 & 139 \\
\cline { 2 - 5 } & $\%$ & 35.71 & 40.66 & 76.37 \\
\hline \hline \multirow{2}{*}{ Village } & Number & 20 & 23 & 43 \\
\cline { 2 - 5 } & $\%$ & 10.99 & 12.64 & 23.63 \\
\hline \multirow{2}{*}{ Total } & Number & 85 & 97 & 182 \\
\cline { 2 - 5 } & $\%$ & 46.70 & 53.30 & 100 \\
\hline
\end{tabular}

Pearson Chi-square $=2.713, \mathrm{df}=1, \mathrm{p}=0.132 \quad *$ significance for $\mathrm{p}<0.05$

Table 5. Treatment method of respondents

\begin{tabular}{|c|c||c|c||c||}
\hline \multirow{2}{*}{\multicolumn{2}{|c|}{ Treatment method }} & \multicolumn{2}{c|}{ Gender } & \multirow{2}{*}{ Total } \\
\cline { 2 - 5 } & & Male & Female & \\
\hline \hline \multirow{2}{*}{ Medication } & Number & 68 & 76 & 144 \\
\cline { 2 - 5 } & $\%$ & 37.36 & 41.76 & 79.12 \\
\hline \hline \multirow{2}{*}{$\begin{array}{c}\text { Laser } \\
\text { Therapy }\end{array}$} & Number & 7 & 9 & 16 \\
\cline { 2 - 5 } & $\%$ & 3.85 & 4.95 & 8.80 \\
\hline \hline \multirow{2}{*}{$\begin{array}{c}\text { Surgical } \\
\text { Therapy }\end{array}$} & Number & 10 & 12 & 22 \\
\cline { 2 - 5 } & $\%$ & 5.49 & 6.59 & 12.08 \\
\hline \hline \multirow{2}{*}{ Total } & Number & 85 & 97 & 182 \\
\cline { 2 - 5 } & $\%$ & 46.70 & 53.30 & 100 \\
\hline
\end{tabular}

Pearson Chi-square $=8.35064, \mathrm{df}=1, \mathrm{p}=0.012465$

One hundred forty-four (79.12\%) male and female respondents were treated with medication, $22(12.08 \%)$ with surgery, and $16(8.80 \%)$ with laser therapy. The analysis of the results indicates a statistical significance in favour of medication, as the most common type of treatment for the subjects, in comparison with the other types of therapy (Pearson Chi-square $=8.5064, \mathrm{df}=1, \mathrm{p}=0.012465$ ).

Depending on the clinical stage in which they were diagnosed with glaucoma, the subjects used anti-glaucomatous treatment for a period of 1-20 years and the analysis of this parameter is presented in Table 6.

Fourteen $(7.69 \%)$ of the male respondents received treatment for $1-5$ years, 32 (17.58\%) for 6-10 years, 29 (15.94\%) for $11-15$ years and 10 $(5.49 \%)$ for a period of $>15$ years, while 21 $(11.54 \%)$ of the female respondents received treatment for a period of $1-5$ years, 34 (18.68\%) for a period of $6-10$ years, $31(17.03 \%)$ for a period of $11-15$ years and $11(6.05 \%)$ for a period of $>15$ years.

Table 6. Descriptive analysis of the duration of antiglaucoma treatment

\begin{tabular}{|c|c||c|c||c||}
\hline \hline \multirow{2}{*}{ Duration of treatment } & \multicolumn{2}{c||}{ Gender } & \multirow{2}{*}{ Total } \\
\cline { 2 - 5 } & & Male & Female & \\
\hline \multirow{2}{*}{$1-5$ years } & Number & 14 & 21 & 35 \\
\cline { 2 - 5 } & $\%$ & 7.69 & 11.54 & 19.23 \\
\hline \hline \multirow{2}{*}{$6-10$ years } & Number & 32 & 34 & 66 \\
\cline { 2 - 5 } & $\%$ & 17.58 & 18.68 & 36.26 \\
\hline \hline \multirow{2}{*}{$\mathbf{1 1 - 1 5}$ years } & Number & 29 & 31 & 60 \\
\cline { 2 - 5 } & $\%$ & 15.94 & 17.03 & 32.97 \\
\hline \hline \multirow{2}{*}{$\mathbf{1 5}$ years } & Number & 10 & 11 & 21 \\
\cline { 2 - 5 } & $\%$ & 5.49 & 6.05 & 11.54 \\
\hline \hline \multirow{2}{*}{ Total } & Number & 85 & 97 & 182 \\
\cline { 2 - 5 } & $\%$ & 46.70 & 53.30 & 100 \\
\hline \hline
\end{tabular}

Pearson Chi-square $=4.37340, \mathrm{df}=2, \mathrm{p}=0.223871$ 
No statistically significant difference was observed between male and female respondents in relation to the duration of prescribed therapy (Pearson Chi-square $=4.37340, \mathrm{df}=2, \mathrm{p}=$ $0.223871)$.

The outcome from the prescribed glaucoma treatment depend on the type of treatment, the manner of administration and adherence to the directions for its use, and the outcome of these examinations is presented in Table 7.

Most of the patients, i.e. 105 of them (57.69\%) adhered to the directions for administration of the treatment, 43 (23.63\%) adhered partially and $34(18.68 \%)$ did not adhere. There is no statistically significant difference in this parameter between male and female patients (Pearson Chisquare $=2.047, d f=3, p=0.563$ ).

Primary open-angle glaucoma is a chronic ophthalmic disease which requires long-term or lifelong treatment with an uncertain prognosis. The analysis of the outcome of the treatment prescribed to the respondents is shown in Table 8.

Thirty-nine $(21.43 \%)$ of the male respondents had negative outcome of the treatment, 25 $(13.73 \%)$ had partial and $21(11.54 \%)$ had positive outcome, whereas $41(22.53 \%)$ of the female respondents had negative, $30(16.48 \%)$ partial and 26
(14.29\%) positive outcome of the treatment. Regarding this parameter, there is no statistically significant difference between male and female respondents (Pearson Chi-square $=4.982$, df $=2, p=$ 0.083).

All the glaucoma cases, due to progressive loss of visual acuity, are accompanied by a social burden which prevents patients from carrying out normal daily functions, movement, self-care and imposes assistance from others, while, at the same time, the unsuccessful outcome of the treatment can cause onset of discomfort, depression and anxiety from complete visual impairment to patients. The analysis of the clinical and pharmacological aspects of the social burden to the respondents is presented in Table 9.

Fourteen (7.69\%) female and 12 (6.59\%) male respondents have a family social burden. Simultaneously, $33(18.13 \%)$ female and 29 (15.93\%) male respondents developed depression, anxiety and discomfort in a more severe form. Regarding these two social parameters, there is no significant difference between female and male respondents (Pearson Chi-square $=2.048, \mathrm{df}=2, \mathrm{p}$ $=0.359$ ).

Table 7. Regularity of prescribing treatment

\begin{tabular}{|c|c||c|c||c||}
\hline \hline \multirow{2}{*}{$\begin{array}{c}\text { Adherence to directions } \\
\text { for treatment }\end{array}$} & \multicolumn{2}{c||}{ Gender } & \multirow{2}{*}{ Total } \\
\cline { 2 - 5 } Yes & Number & 49 & 56 & 105 \\
\cline { 2 - 5 } & $\%$ & 26.92 & 30.77 & 57.69 \\
\hline \hline \multirow{2}{*}{ Partially } & Number & 20 & 23 & 43 \\
\cline { 2 - 5 } & $\%$ & 10.99 & 12.64 & 23.63 \\
\hline \hline \multirow{2}{*}{ No } & Number & 16 & 18 & 34 \\
\cline { 2 - 5 } & $\%$ & 8.79 & 9.89 & 18.68 \\
\hline \hline \multirow{2}{*}{ Total } & Number & 85 & 97 & 182 \\
\cline { 2 - 5 } & $\%$ & 46.70 & 53.30 & 100 \\
\hline \multicolumn{2}{|c|}{ Pearson Chi-square $=2.047, \mathrm{df}=3, \mathrm{p}=0.563$} & *significance for $\mathrm{p}<0.05$ \\
\hline
\end{tabular}

Table 8. Outcome of treatment of respondents

\begin{tabular}{||c|c||c|c||c||}
\hline \multicolumn{2}{|c|}{ Outcome of treatment } & \multicolumn{2}{c||}{ Gender } & \multirow{2}{*}{ Total } \\
\cline { 2 - 5 } Successful treatment & Number & 21 & 26 & 47 \\
\cline { 2 - 5 } & $\%$ & 11,54 & 14,29 & 25,82 \\
\hline \hline \multirow{2}{*}{$\begin{array}{c}\text { Partial success of } \\
\text { treatment }\end{array}$} & Number & 25 & 30 & 55 \\
\cline { 2 - 5 } & $\%$ & 13,73 & 16,48 & 30,22 \\
\hline \hline $\begin{array}{c}\text { Negative outcome of } \\
\text { treatment }\end{array}$ & Number & 39 & 41 & 80 \\
\cline { 2 - 5 } & $\%$ & 21,43 & 22,53 & 43,96 \\
\hline \hline \multirow{2}{*}{ Total } & Number & 85 & 97 & 182 \\
\cline { 2 - 5 } & $\%$ & 46,70 & 53,30 & 100 \\
\hline Pearson Chi-square $=4.982, \mathrm{df}=2, \mathrm{p}=0.083$ & \multicolumn{3}{c}{$*$ significance for $\mathrm{p}<0.05$} \\
\hline
\end{tabular}


Table 9. Social burden on the respondents

\begin{tabular}{|c|c||c|c||c||}
\hline \multicolumn{2}{|c||}{ Social burden } & \multicolumn{2}{c|}{ Gender } & \multirow{2}{*}{ Total } \\
\cline { 3 - 5 } Family burden & Number & 12 & 14 & 26 \\
\cline { 2 - 5 } & $\%$ & 6.59 & 7.69 & 14.28 \\
\hline \hline \multirow{2}{*}{ Discomfort/depression/anxiety } & Number & 29 & 33 & 62 \\
\cline { 2 - 5 } & $\%$ & 15.93 & 18.13 & 34.07 \\
\hline \hline \multirow{2}{*}{ Total } & Number & 41 & 47 & 88 \\
\cline { 2 - 5 } & $\%$ & 22.52 & 25.82 & 48.35 \\
\hline Pearson Chi-square $=2.048, \mathrm{df}=2, \mathrm{p}=0.359$ & \multicolumn{2}{|c}{$*$ significance for $\mathrm{p}<0.05$} \\
\hline
\end{tabular}

\section{Discussion}

The current findings indicate the existence of complex exact relations and connection of the social burden with the impairment of the visual acuity, the clinical stage and treatment of the disease and the socio-demographic parameters in the patients (2729).

Our research demonstrates that in primary glaucoma, female patients are more frequent $(53.30 \%)$ compared to male $(46.70 \%)$, whereby from the total number, $19.23 \%$ were aged $20-50$, $42.86 \%$ were $51-60$ and $37.91 \%$ were $61-67$ years of age.

Gender has no pathognomonic significance in the occurrence of glaucoma, but it has been proven that of all the glaucoma cases $50-55 \%$ are female, while in primary closed-angle glaucoma cases females dominate with $70 \%$ of the total number $(6,9$, 30).

With reference to age, according to the WHO program "Right to Sight 2020", the number of visually impaired people progressively increases with age, $31 \%$ of the people with severe forms of visual impairment and blindness were aged 45-59, and $58 \%$ were over 60 years of age $(31,32)$.

Primary open-angle glaucoma is treated with medication, laser and surgery and it is administered at home, on an outpatient basis or in an inpatient setting $(33,34)$.

Most of the respondents, i.e. $79.12 \%$ were treated with medication, $8.80 \%$ with laser therapy and $12.08 \%$ with surgical treatment.

The medical treatment includes the use of mono and combined antiglaucoma medication, beta blockers, carbonic anhydrase inhibitors, alpha 2 antagonists, prostaglandin analogues, miotics, neuroprotective and multivitamin and other medication (35-37).

If the application of antiglaucoma medication does not normalize the intraocular pressure, argon, diogen or similar types of laser therapy are indicated (38-40) or the application of various surgical treatment techniques (41-43).

Despite the regular treatment, which was adhered to by $57.69 \%$ of the respondents, glaucoma is an optical progressive neuropathy with an uncertain outcome of treatment, and in our study it was determined that in $43.96 \%$ of the cases the treatment had a negative outcome with further loss of visual acuity, partial success of treatment in $30.22 \%$ cases and in $25.82 \%$ of the respondents the treatment was successful and prevented further vision loss.

The reason for not adhering to the medical treatment is usually the insufficient patient education about the essence of the disease $(14,44,45)$ or the high costs of prescription medicine and the economic burden they cause $(46,47)$.

A cross-sectional study which examined the social burden of outpatient care on glaucoma patients in Cairo found that $88 \%$ of 68 patients did not attend outpatient appointments, 40 of whom did not do so due to lack of education and 28 for economic reasons (48).

The disproportion between the increased treatment costs and the reduced income due to productivity loss, in $14.28 \%$ of the respondents was reflected with the occurrence of social family burden, and in $34.07 \%$ of the respondents the progressive loss of visual acuity caused discomfort, depression, anxiety, hopelessness and other psychosocial disorders that have adversely affected their healthrelated quality of life (HRQL). A retrospective study conducted in the United States to assess social burden with DALY states that there is a trend of progression of social burden on people with lower social status and older age, while it also observed that there is higher social burden on women rather than men in all age groups. The largest increase in the social burden was registered among people with reproductive ability at the age of 60 and in patients older than 75 (49). Early diagnosis in the initial stage of the disease, availability of medication and proper administration of treatment with regular ophthalmological examinations, in $70-80 \%$ of cases can lead to a positive outcome, prevention of progression of the disease and occurrence of blindness $(44,45,50,51)$.

\section{Conclusion}

Primary open-angle glaucoma generates a significant socio-economic burden as a result of irreversible visual impairment, reduced work ability and productivity, and high treatment costs of patients.

The impact of the social burden depends on the degree of visual impairment, clinical stage of the 
disease, adequacy, method of administration, regularity and treatment costs and socio-demographic parameters such as gender, age, genetic predis- position, race, comorbid conditions, familial predisposition, etc. which in glaucoma play the role of predisposing risk factors.

\section{References}

1. Kocur I., Resnicoff S., Visual impairments and blindness in Europe and their prevention. $\mathrm{Br} \mathrm{J}$ Ophthalmol. 2002;86:716-22. [CrossRef] [PubMed]

2. Naidoo KS, Leasher J, Bourne RR, Flaxman SR, Jonas JB, Keeffe J, et al. Global vision impairment and blindness due to uncorrected refractive error, 19992010. Optom Vis Sci. 2016;93:227-34. [CrossRef] [PubMed]

3. Lau JTF, Lee V, Fan D, Lau M, Michon J. Knowledge about cataract, glaucoma, and age related macular degeneration in the Hong Kong Chinese population. $\mathrm{Br}$ J Ophthalmol. 2002;86(10):1080-4.

\section{[CrossRef] [PubMed]}

4. Casson RJ, Chidlow G, Wood JP, Crowston JG, Goldberg I. Definition of glaucoma: clinical and experimental concepts. Clin Experiment Ophthalmol. 2012;40(4):341-9. [CrossRef] [PubMed]

5. Weinreb RN, Aung T, Medeiros FA. The pathophysiology and treatment of glaucoma: a review. JAMA. 2014;311(18):1901-11. [CrossRef] [PubMed]

6. Quigley HA, Broman AT. The number of people with glaucoma worldwide in 2010 and 2020. Br J Ophthalmol. 2006;90(3):262-7. [CrossRef] [PubMed]

7. Cook C, Foster P. Epidemiology of glaucoma: what's new? Can J Ophthalmol. 2012;47(3):223-6.

[CrossRef] [PubMed]

8. Geimer SA. Glaucoma diagnostics. Acta Ophthalmol 2013;91 Thesis 1:1-32. [CrossRef] [PubMed]

9. Prum BE, Rosenberg LF, Gedde S], Mansberger SL, Stein JD, Moroi SE, et al. Primary Open-Angle Glaucoma Preferred Practice Pattern((R)) Guidelines. Ophthalmology. 2016;123(1):P41-P111.

\section{[CrossRef] [PubMed]}

10. European Glaucoma Society. European Glaucoma Society Guidelines (2014). Terminology and Guidelines for Glaucoma. $4^{\text {th }}$ edn. Savona, Italy: Editrice DOGMA;2014;79-89.

11. Quigley HA. Glaucoma. Lancet. 2011;377(9774): 1367-77. [CrossRef] [PubMed]

12. Sarenac-Vulovic T, Janicijevic K. Primary open-angle glaucoma and pharmacoeconomics: Review. Sanamed. 2016;11(3):243-8. [CrossRef]

13. Grekova D, Andreevska K, Petrova G, Petkova V. Assessment of the social and economic burden of glaucoma in Bulgaria. Biomedical Research. 2018; 29(12):2578-81. [CrossRef]

14. Poulsen PB, Buchholz P, Walt JG, Christensen TL, Thygensen J. Cost analysis of glaucoma-related- blindness in Europe. International Congress Series. 2005; 1282:262-6. [CrossRef]

15. Peters D, Heijl A, Brenner L, Bengtsson B. Visual impairment and vision-related quality of life in the Early Manifest Glaucoma Trial after 20 years of followup. Acta Ophthalmol. 2015;93(8):745-52.

[CrossRef] [PubMed]

16. Brown RL, Barrett AE. Visual impairment and quality of life among older adults: an examination of explanations for the relationship. The Journals of $\mathrm{Ge}$ rontologySeries B: Psychological Sciences and Social Sciences. 2011;66(3):364-73. [CrossRef] [PubMed]

17. Belevska M, Jovanovic J, Gjosevska-Dastevska E, Velkovski Z. The importance of individual predictors and psychosocial working conditions in assessing the work ability index of people with low vision. Int ] Occup Saf Ergon. 2021;27(2):442-51. [CrossRef] [PubMed]

18. Baudouin C, Renard JP, Nordmann JP, Denis P, Lachkar Y, Sellem E, et al. Prevalence and risk factors for ocular surface disease among patients treated over the long term for glaucoma or ocular hypertension. Eur ] Ophthalmol. 2012;0. [CrossRef] [PubMed]

19. Leung EW, Medeiros F, Weinreb RN. Prevalence of ocular surface disease in glaucoma patients. J Glaucoma. 2008;17(5):350-5. [CrossRef] [PubMed]

20. Uusitalo $H$, Chen $E$, Pfeiffer N, Brignole-Baudouin $F$, Kaarniranta $K$, Leino $M$, et al. Switching from a preserved to a preservative-free prostaglandin preparation in topical glaucoma medication. Acta Ophthalmol. 2010;88(3):329-36. [CrossRef] [PubMed]

21. Pisella PJ, Pouliquen P, Baudouin C. Prevalence of ocular symptoms and signs with preserved and preservative free glaucoma medication. $\mathrm{Br} \mathrm{J}$ Ophthalmol. 2002;86(4):418-23. [CrossRef] [PubMed]

22. Nayak B, Gupta S, Kumar G, Dada T, Gupta V, Sihota $\mathrm{R}$. Socioeconomics of long-term glaucoma therapy in India. Indian J Ophthalmol 2015;63(1):20-4. [CrossRef] [PubMed]

23. Mansberger SL, Sheppler CR, McClure TM, Vanalstine CL, Swanson IL, Stoumbos Z, et al. Psychometrics of a new questionnaire to assess glaucoma adherence: the Glaucoma Treatment Compliance Assessment Tool (an American Ophthalmological Society thesis). Trans Am Ophthalmol Soc. 2013;111:1-16.

24. Odberg T, Jakobsen JE, Hultgren SJ, Halseide R. The impact of glaucoma on the quality of life of patients in 
Norway. Results from a self-administered questionnaire. Acta Ophthalmol Scand. 2001;79(2):116-20. [CrossRef] [PubMed]

25. Floriani I, Quaranta L, Rulli E, Katsanos A, Varano L, Frezzotti $P$, et al. Health-related quality of life in patients with primary open-angle glaucoma. An Italian multicentre observational study. Acta Ophthalmol. 2016;94(5):e278-e286. [CrossRef] [PubMed]

26. Quaranta L, Riva I, Gerardi C, Oddone F, Floriani I, Konstas AGP. Quality of life in glaucoma: a review of the literature. Adv Ther. 2016;33(6):959-81.

[CrossRef] [PubMed]

27. Friedman DS, Wolfs RCW, O Colmain BJ, Klein BE, Taylor HR, West S, et al. Prevalence of open-angle glaucoma among adults in the United States. Arch Ophthalmol. 2004;122(4):532-8. [CrossRef] [PubMed]

28. Chong EW, Lamoureux EL, Jenkins MA, Aung T, Saw SM, Wong TY. Sociodemographic, lifestyle and medical risk factors for visual impairment in an urban asian population: the singapore malay eye study. Arch Ophthalmol. 2009;127(12):1640-7.

[CrossRef] [PubMed]

29. Tham YC, Li X, Wong TY, Quigley H, Aung T, Cheng $\mathrm{CY}$. Global prevalence of glaucoma and projections of glaucoma burden through 2040: a systematic review and meta-analysis. Ophthalmology. 2014;121(11): 2081-90. [CrossRef] [PubMed]

30. Rudnicka AR, Mt-Isa S, Owen CG, Cook DG, Ashby D. Variations in primary open-angle glaucoma prevalence by age, gender, and race: a Bayesian meta-analysis. Invest Ophthalmol Vis Sci. 2006;47(10):4254-61. [CrossRef] [PubMed]

31. Pizzarello $L$, Abiose A, Ffytche $T$, Duerksen $R$, Thulasiraj R, Taylor $\mathrm{H}$, et al. VISION 2020: The right to sight: a global initiative to eliminate avoidable blindness. Arch Ophthalmol. 2004;122(4):615-20. [CrossRef] [PubMed]

32. Rein DB, Zhang $P$, Wirth KE, Lee PP, Hoerger TJ, McCall N, et al. The economic burden of major adult visual disorders in the United States. Arch Ophthalmol. 2006;124(12):1754-60. [CrossRef] [PubMed]

33. Bagnis A, Papadia M, Scotto R, Traverso CE. Current and emerging medical therapies in treatment of glaucoma. Expert Opin Emerg Drugs. 2011;16(2):293307. [CrossRef] [PubMed]

34. Feiner L, Piltz-Seymour JR. Collaborative initial glaucoma treatment study: a summary of results to date. Curr Opin Ophthalmol. 2003;14(2):106-11. [CrossRef] [PubMed]

35. Servat JJ, Bernardino CR. Effects of common topical antiglaucoma medications on the ocular surface, eyelids and periorbital tissue. Drugs Aging. 2011; 28(4):267-82. [CrossRef] [PubMed]

36. Babić N. Medikamentozna terapija glaukoma. Novi Sad: Medicinski fakultet Univerziteta u Novom Sadu 2013;5-6.

37. Vasudevan SK, Gupta V, Crowston JG. Neuroprotection in glaucoma. Indian J Ophthalmol. 2011; 59 Suppl(Suppl1):S102-13. [CrossRef] [PubMed]
38. Koucheki B, Hashemi H. Selective laser trabeculoplasty in the treatment of open-angle glaucoma. ] Glaucoma. 2012;21(1):65-70. [CrossRef] [PubMed]

39. Kara N, Altan C, Yuksel K, Tetikoglu M. Comparison of the efficacy and safety of selective laser trabeculoplasty in cases with primary open-angle glaucoma and pseudoexfoliative glaucoma. Kaohsiung J Med Sci. 2013;29(9):500-4. [CrossRef] [PubMed]

40. Samples JR, Singh K, Lin SC, Francis BA, Hodapp E, Jampel HD, et al. Laser trabeculoplasty for open angle glaucoma: a report by the american academy of ophthalmology. Ophthalmology. 2011;118(11):2296302. [CrossRef] [PubMed]

41. Rachmiel R, Trope GE, Chipman ML, Gouws P, Buys YM. Effect of medical therapy on glaucoma filtration surgery rates in Ontario. Arch Ophthalmol. 2006; 124(10):1472-7. [CrossRef] [PubMed]

42. Burr J, Azuara-Blanco A, Avenell A, Tuulonen A. Medical versus surgical interventions for open angle glaucoma. Cochrane Database Syst Rev. 2012;(9): CD004399. [CrossRef] [PubMed]

43. Kim HY, Egbert PR, Singh K. Long-term comparison of primary trabeculectomy with 5-fluorouracil versus mitomycin C in West Africa. J Glaucoma. 2008;17(7): 578-83. [CrossRef] [PubMed]

44. Leite MT, Sakata LM, Medeiros FA. Managing glaucoma in developing countries. Arq Bras Oftalmol. 2011;74(2):83-4. [CrossRef] [PubMed]

45. Vaahtoranta-Lehtonen $H$, Tuulonen $A$, Aronen $P$, Sintonen $H$, Suoranta $L$, Kovanen $N$, et al. Cost effectiveness and cost utility of an organized screening programme for glaucoma. Acta Ophthalmol Scand. 2007;85(5):508-18. [CrossRef] [PubMed]

46. Castro AN, Mesquita WA. Noncompliance with drug therapy for glaucoma. Arq Bras Oftalmol. 2008; 71(2):207-14. [CrossRef] [PubMed]

47. Fiscella RG, Lee J, Davis EJH, Walt J. Cost of illness of glaucoma: a critical and systematic review. Pharmacoeconomics. 2009; 27(3):189-98. [CrossRef] [PubMed]

48. Eldaly $M$, Hunter $M$, Khafagy $M$. The socioeconomic impact among Egyptian glaucoma patients. $\mathrm{Br} \mathrm{J}$ Ophthalmol. 2007;91(10):1274-5. [CrossRef] [PubMed]

49. Wang W, He M, Li Z, Huang W. Epidemiological variations and trends in health burden of glaucoma worldwide. Acta Ophthalmol. 2019;97(3):e349-e355. [CrossRef] [PubMed]

50. Orme M, Collins S, Loftus J. Long-term medical management of primary open-angle glaucoma and ocular hypertension in the UK: Optimizing costeffectiveness and clinic resources by minimizing therapy switches. J Glaucoma. 2012;21(7) 433-49. [CrossRef] [PubMed]

51. Shih V, Parekh M, Multani JK, McGuiness CB, Chen CC, Campbell JH, et al. Clinical and economic burden of glaucoma by disease severity: a United States claims-based analysis. Ophthalmol Glaucoma. 2021; 4(5):490-503. [CrossRef] [PubMed] 


\title{
PROCENA SOCIJALNOG OPTEREĆENJA BOLESNIKA SA PRIMARNIM GLAUKOMOM OTVORENOG UGLA
}

\author{
Zoran Velkovski ${ }^{1}$, Maja Belevska², Emilija Gjosevska Dastevska
}

${ }^{1}$ Klinička bolnica Bitolj, Odeljenje za laboratorijsku dijagnostiku, Bitolj, Severna Makedonija
${ }^{2}$ Klinička bolnica Bitolj, Odeljenje za oftalmologiju, Bitolj, Severna Makedonija
${ }^{3}$ Medicinski fakultet Skoplje, Klinika za očne bolesti, Skoplje, Severna Makedonija

Kontakt: Zoran Velkovski

Partizanska bb, 7000 Bitola, Severna Makedonija

E-mail: zoranv_mk@yahoo.com

Glaukom je hronična oftalmološka bolest koju karakteriše progresivan, nepovratan gubitak vidne oštrine, dugotrajna progresija i doživotno lečenje, opadanje radne sposobnosti i samodovoljnosti, što može da generiše socijalno opterećenje kod bolesnika. Studija je dizajnirana tako da obuhvati socijalne, kliničke i farmakološke aspekte procene društvenog opterećenja bolesnika primarnim glaukomom otvorenog ugla. Reč je o studiji preseka sa kvantitativnim analitičkim pristupom, koja obuhvata 182 bolesnika muškog i ženskog pola, sa primarnim glaukomom otvorenog ugla, starosti od 20 do 67 godina, sa očuvanom oštrinom vida > 6/18 $(0,33)$, prema ICD-10 klasifikaciji, sprovedena u periodu od avgusta do novembra 2020. godine na teritoriji Severne Makedonije. 53,3\% ispitanika činile su žene i $46,7 \%$ činili su muškarci, od kojih je $79,12 \%$ lečeno propisanim lekovima, $8,8 \%$ laserom i $12,08 \%$ podvrgnuto je hirurškom zahvatu. Redovno se lečilo $57,69 \%$ ispitanika, $43,96 \%$ imalo je negativan ishod, delimičan uspeh u $30,22 \%$, a kod $25,82 \%$ ispitanika lečenje je sprečilo dalji gubitak vida. $14,28 \%$ ispitanika iskusilo je socijalno i porodično opterećenje, a $34,07 \%$ nelagodnost, depresiju, anksioznost, beznađe i druge psihosocijalne poremećaje. Primarni glaukom otvorenog ugla stvara značajan socio-ekonomski teret, kao rezultat nepovratnog oštećenja vida, smanjene radne sposobnosti i produktivnosti i visokih troškova lečenja bolesnika. Stepen socijalnog opterećenja zavisi od razvoja i kliničkog stadijuma bolesti, procenta očuvanog vida, dostupnosti, načina i redovnosti lečenja i socio-demografskih parametara, kao što su pol, starost, zanimanje, genetska predispozicija, komorbidna stanja, porodična anamneza i dr., koji kod glaukoma igraju ulogu predisponirajućih faktora rizika.

Acta Medica Medianae 2021;60(4):30-38.

Ključne reči: primarni glaukom otvorenog ugla, socijalno opterećenje, sociodemografski parametri, terapija 